\title{
AN ANALYSIS OF FRENCH MERGERS AND ACQUISITIONS IN DIFFERENT SECTORS OF THE CZECH ECONOMY
}

\section{Thivant, E., Machková, H.}

Over the past two decades, French enterprises have been heavily investing in the Czech Republic. Today, France is the fifth biggest investor to the Czech Republic, and French companies are among the most important employers. The aim of this study is to analyze the presence of French firms in Czech Republic by look at the example the French-Czech mergers and acquisitions (M\&A), and to explain the main motivation of the location of French firms in the country. Using a review of documents and secondary data analysis, we observe that French enterprises have invested especially in the Czech manufacturing sector, energy \& power, consumer staples and financial services. In this study, we evaluate if French corporations try to optimize their production process within so-called global value chains, and if French companies have invested in their own strategic domain area or another strategic area by using the diversification growth approach. Finally, we present examples of successful mergers and acquisitions of French firms realized in the Czech Republic.

Keywords: mergers; acquisitions; France; investment; Czech Republic; FDI; OLI theory JEL Classification: L1, L6

\section{Introduction}

The goal of this study is to analyze the presence of French firms in the Czech Republic by taking a look at French-Czech mergers and acquisitions (M\&A), their ownership structure and main motivation and results of the location of the production and/or business activities in the country. Today, twenty-six years after the fall of the iron curtain, and with the new economic reforms after 1993, French enterprises have been continuously investing in the Czech Republic. Economic indicators such as GDP growth or inflation rate were very attractive for international investors (see Table 1), especially during the 20002005 period. And these good figures, together with the country location in Central Europe and relatively cheap and qualified labor force, explain the development of French-Czech mergers and acquisitions (M\&A).

Over the past two decades, international investors have continuously invested in Czech Republic, as illustrated in the Figure 1, with the flow of Foreign Direct Investment (FDI) over the period 1993-2014.

To define FDI, we may use the explanation of UNCTADSTAT (2014b) stating that "UN FDI inflows comprise capital provided (either directly or through other related enterprises) by a foreign direct investor to a FDI enterprise, or capital received by a foreign direct investor from a FDI enterprise. FDI includes the following three components: equity capital, reinvested earnings and intra-company loans.

- Equity capital is the foreign direct investor's purchase of shares of an enterprise in a country other than its own.

- Reinvested earnings comprise the direct investor's share (in proportion to direct equity participation) of earnings not distributed as dividends by affiliates or earnings not remitted to the direct investor. Such retained profits by affiliates are reinvested. 
- Intra-company loans or intra-company debt transactions refer to short- or long-term borrowing and lending of funds between direct investors (parent enterprises) and affiliate enterprises."

Table 1 | Summary of the main indicators for Czech Republic (1994-2014)

\begin{tabular}{|l|r|r|r|r|r|r|}
\hline Year & \multicolumn{1}{|c|}{1994} & \multicolumn{1}{c|}{1995} & \multicolumn{1}{c|}{$\mathbf{2 0 0 0}$} & \multicolumn{1}{c|}{$\mathbf{2 0 0 5}$} & \multicolumn{1}{c|}{$\mathbf{2 0 1 0}$} & \multicolumn{1}{c|}{$\mathbf{2 0 1 4}$} \\
\hline GDP (millions \$) & 47364.73 & 59535.61 & 61469.61 & 135990.12 & 207016.40 & 205269.70 \\
\hline $\begin{array}{l}\text { GDP Growth } \\
\text { (annual \%) }\end{array}$ & 2.90 & 6.22 & 4.29 & 6.44 & 2.29 & 10543 \\
\hline $\begin{array}{l}\text { Population (millions } \\
\text { of people) }\end{array}$ & 10339 & 10336 & 10263 & 10231 & 10507 & 19490 \\
\hline $\begin{array}{l}\text { GDP per capita at PPP } \\
\text { (US \$) }\end{array}$ & 4581 & 5760 & 5989 & 13292 & 19703 & 0.36 \\
\hline Inflation rate (\%) & 10.04 & 9.12 & 3.91 & 1.88 & 1.46 & 29 \\
\hline
\end{tabular}

Source UNCTADSTAT (2014a).

Figure 1 | Czech Republic Foreign Direct Investment Inflow

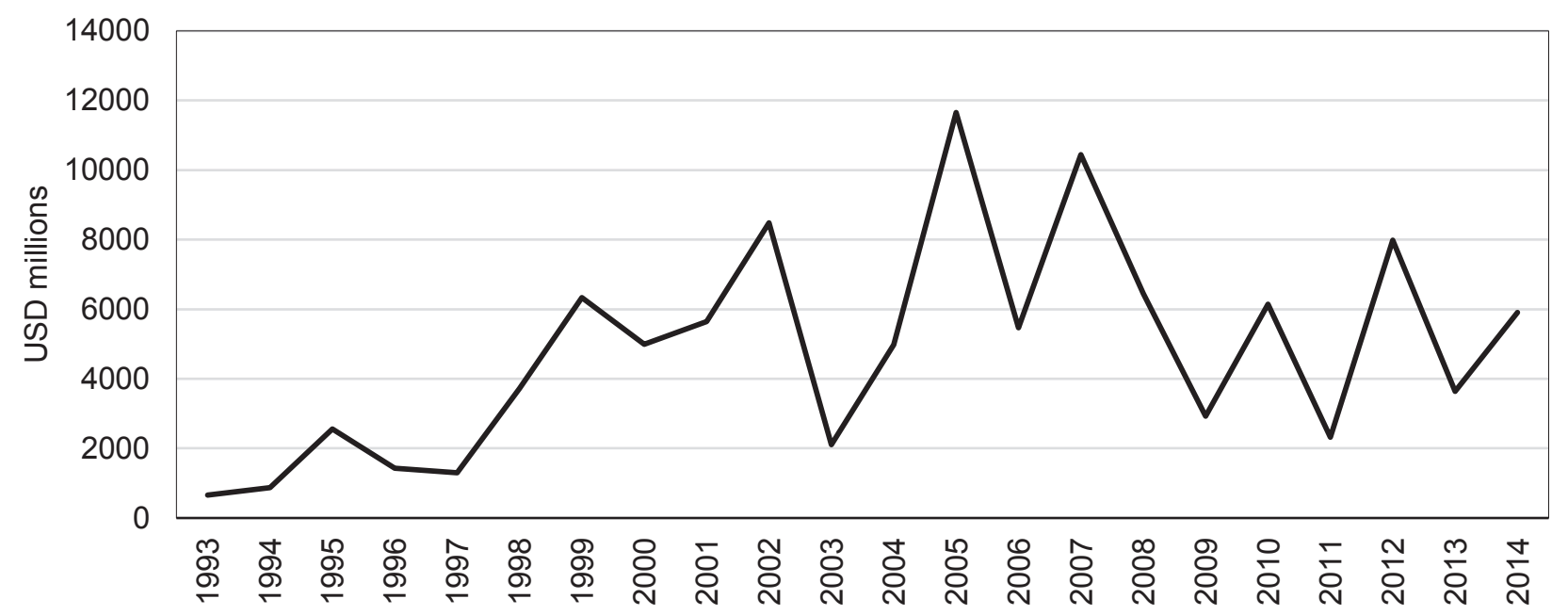

Source: UNCTADSTAT (2014a)

Table 2 illustrates the structure of FDI by the end of 2014. The stock of foreign investment in the Czech Republic amounted to 121.5 billion USD. The largest share of foreign capital went to manufacturing (33.4\%), financial and insurance activities (25.4\%) and wholesale and retail trade, repair of motor vehicles and motorcycles $(10.7 \%)$.

France was the $5^{\text {th }}$ biggest investor with $6.1 \%$ share. The greatest share of capital invested comes from the Netherlands (24\%) and neighboring countries Austria (13.2\%) and Germany (12.6\%), followed by the Luxembourg (12.1\%). 
Table 2 | Volume of FDI in the Czech Republic (December 31, 2014)

\begin{tabular}{|l|c|c|c|c|c|}
\hline & Equity capital & $\begin{array}{c}\text { Reinvested } \\
\text { earnings }\end{array}$ & $\begin{array}{c}\text { Equity capital } \\
\text { +reinvested } \\
\text { earnings }\end{array}$ & Other capital & $\begin{array}{c}\text { Total at book } \\
\text { value }\end{array}$ \\
\hline & $\mathbf{1 .}$ & $\mathbf{2 .}$ & $\mathbf{1 . + 2 .}$ & $\mathbf{3 .}$ & $\mathbf{1 . + 2 . + 3 .}$ \\
\hline CZK billion & $1,332.9$ & $1,189.9$ & $2,522.8$ & 251.8 & $2,774.6$ \\
\hline USD billion & 58.4 & 52.1 & 110.5 & 11.0 & 121.5 \\
\hline
\end{tabular}

Source: ČNB (2016).

French enterprises have invested mostly in Czech manufacturing industry, energy $\&$ power, consumer staples and financial services. In this study, we analyze if it's more the horizontal or vertical business process engaged and if they have invested in their own strategic domain area or another strategic area by opting for the diversification strategy.

The remainder of this paper is structured as follows. First, we present the review of relevant literature on international management, the entry mode for enterprises in a new country and the relationships with mergers and acquisitions (M\&A). Then, we analyze the French-Czech relationships with mergers and acquisitions both globally and with respect to economic sectors. Finally, discussion and concluding remarks are presented.

\section{Theoretical Framework: International Business and Mergers and Acquisitions}

To achieve competitive advantage, international firms use different entry modes to enter foreign markets. There is an overall academic consensus on the fact that international firms are key players in the world economy (Mayrhofer, 2012). Their way of development of international activities differs from one enterprise to another; generally, not all international firms are "born globals". What is more, most multinational companies actually operate regionally, not globally (Rugman and Verbeke, 2004).

In the international management literature, we can find more than six paradigms (Dunning, 2000), such as managerial related paradigms, organizational paradigm, marketing paradigm (Johanson \& Vahlne, 1977), technological paradigm (Cantwell, 1989; Cantwell, 1994), modern paradigm of international trade, finance paradigm, or the OLI paradigm.

According to Dunning (2000), the OLI paradigm (the three letters originating from ownership, location and internalization), also known as the eclectic paradigm, "has remained the dominant analytical framework for accommodating a variety or operationally testable economic theories of the determinants of foreign direct investment (FDI) and the foreign activities of multinational enterprises (MNEs)". According to this paradigm, firms develop internationally if they find advantages in ownership, location and internalization (Dunning, 1993). For the purpose of this paper, we will use this paradigm (Chalencon \& Dominguez, 2014) and some theories from inside of this framework.

According to Canabal and White (2008), there are more than ten interesting theories such as transaction-cost theory, internalization theory, institutional theory, resource-based view theory, FDI theory, etc. which can be used for analyzing entry modes of international 
firms. The authors state that the transaction cost theory has been the most commonly used theory in entry mode studies. This theory is based upon the idea that "firms need to create governance structures that will minimize costs and inefficiencies associated with entering and operating in a foreign market" (Canabal \& White, 2008). So from this viewpoint, mergers and acquisitions will reduce costs (such as spatial transactions costs) and inefficiencies by setting up of a new business in a new country.

Theories of risk diversification are useful to understand the "location" aspect of the eclectic paradigm, i.e. specific advantages of countries. Based on the existing literature, Dunning (2000) argues that firms "will diversify their portfolios to minimize their risks exposures, which include exchange, political and economic risks". According to Mohelský and Machková (2012), the geographical diversification is particularly important, as it allows companies to take advantage of uneven development and different phases of the economic cycle in a multiple countries and markets. Mergers and acquisitions are useful for diversification, but still, they may be associated with several risks related to poor timing or knowledge about the assets that are acquired (Dunning, 2000).

Before proceeding further, we will precise the concept of "mergers \& acquisitions" and their relations to the international management theory.

According to Tort (2010), we should distinguish mergers from acquisitions. An acquisition "occurs when one company takes a controlling ownership interest in another firm, or selected assets of another firm such as a manufacturing facility" (DePamphilis, 2008). As to mergers, they are usually defined as "a combination of two or more firms in which all but one legally cease to exist, and the combined organization continues under the original name of the surviving firm" (DePamphilis, 2008).

Mergers can aim to increase economic efficiency, to acquire market power, to diversify, to expand into different geographic markets, to pursue financial and research and development synergies, among others (Machková, 2010). From the economic perspective, business combinations can be classified into horizontal, vertical and conglomerate mergers (DePhamphilis, 2008). While vertical mergers allow for controlling adjacent stages of production (Fan \& Goyal, 2006), horizontal mergers concern the same industries, and aim to increase the market share or benefit from synergies.

Based on the eclectic paradigm, Dunning (2000) hypothesizes that "some sectors, e.g. the oil and pharmaceutical sectors, are likely to generate more FDI than others, e.g. the iron and steel or aircraft sectors, because the characteristics of the former generate more unique "O" advantages, and/or because their location need favor production outside their home countries, and/or because the net benefits of internalizing cross-border intermediate products markets are greater". In this article, we will evaluate if there is supporting evidence for this proposition in the Czech Republic. Moreover, we will also evaluate if, due to the theories of risk diversifications and specific transaction costs, horizontal mergers $\&$ acquisitions occur more frequently than vertical mergers \& acquisitions.

\section{Methodology and Data}

For the purposes of our analysis, we used the database Thomson ONE Banker - Deals SDC PLATINUM. This database, which has existed since 1979, contains essential information about mergers and acquisitions and the new issues of stock and obligations (equity and debt exits). It offers global information about markets and sectors, such as: news, 
evolution of prices, economic events, main indications and constituents, exchange rate, compulsory return, or interest rate. To search for relevant data, we have used different filters: nationality of the actors, activity of the actors, date operations with announcement and outcome, going (taking) up operations, type of operation. Target nations were France and the Czech Republic.

In total, we have found 118 mergers and acquisitions from France to the Czech Republic which occurred between 1993 and 2013. The deals, which have been presented in the database, are deals for more than $5 \%$ of share of the enterprise and/or the value of the deal is superior to $3 \%$ and more than 1 million USD.

\section{Global Acquisitions Analysis about French-Czech Enterprises}

Out of 118 M\&A operations that have been already declared, 92 operations have been completed between 1993 and 2013 and 26 operations are pending (PO), have unknown status (USO) or are listed as intended operations (IO). Table 3 illustrates their industry affiliations.

Table 3 | Mergers and acquisitions from France to the Czech Republic (1993-2013)

\begin{tabular}{|l|c|c|c|}
\hline Industry Affiliation & Total & Completed & Status (PO, USO, IO) \\
\hline Consumer Products and Services & 9 & 5 & 4 PO \\
\hline Consumer Staples & 15 & 14 & 1 PO \\
\hline Energy and Power & 21 & 13 & 6 (4PO + 2 USO) \\
\hline Financials & 10 & 8 & 1 PO \\
\hline Healthcare & 4 & 4 & 0 PO \\
\hline High Technology & 5 & 4 & 1 PO \\
\hline Manufacturing Industry & 33 & 26 & 7 (4 PO+2 USO + 1 IO) \\
\hline Materials & 12 & 10 & 2 (1 USO + 1 IO) \\
\hline Media and Entertainment & 4 & 4 & 0 PO \\
\hline Real Estate & 1 & 1 & 0 PO \\
\hline Retail & 3 & 2 & 1 PO \\
\hline Telecommunications & 1 & 1 & 0 PO \\
\hline Total & $\mathbf{1 1 8}$ & $\mathbf{9 2}$ & $\mathbf{2 6}$ (18 PO +6 USO + 2 IO) \\
\hline
\end{tabular}

Source: authors' own calculation based on database One Banker - Deals - SDC

Concerning the 92 completed operations we can see in Table 4, there are three "peaks" of investment: during the first decade, the first peak is during 1993-1996, the second peak is $2000-2001$, and the third peak is 2006-2008. 
Table 4 | Number of completed M\&As in the Czech Republic by French acquirers

\begin{tabular}{|l|c|c|c|c|c|c|c|c|c|c|}
\hline Year & 1993 & 1994 & 1995 & 1996 & 1997 & 1998 & 1999 & 2000 & 2001 & 2002 \\
\hline No. of M\&As & 4 & 1 & 8 & 5 & 4 & 3 & 5 & 4 & 8 & 2 \\
\hline Year & 2003 & 2004 & 2005 & 2006 & 2007 & $\mathbf{2 0 0 8}$ & $\mathbf{2 0 0 9}$ & $\mathbf{2 0 1 0}$ & 2011 & 2012 \\
\hline No. of M\&As & 2 & 2 & 2 & 6 & 11 & 11 & 3 & 5 & 2 & 4 \\
\hline
\end{tabular}

Source: own calculation based on database One Banker - Deals - SDC

We can also illustrate graphically the time series (Figure 2). It can be assumed that the time development has been influenced by the integration of the Czech Republic in the European Union and the international economy, as well as reforms undertaken in the Czech Republic. Supposedly, the global financial crisis can also explain the behavior of French investors in the Czech Republic.

Figure 2 | Number of completed M\&As in the Czech Republic by French acquirers

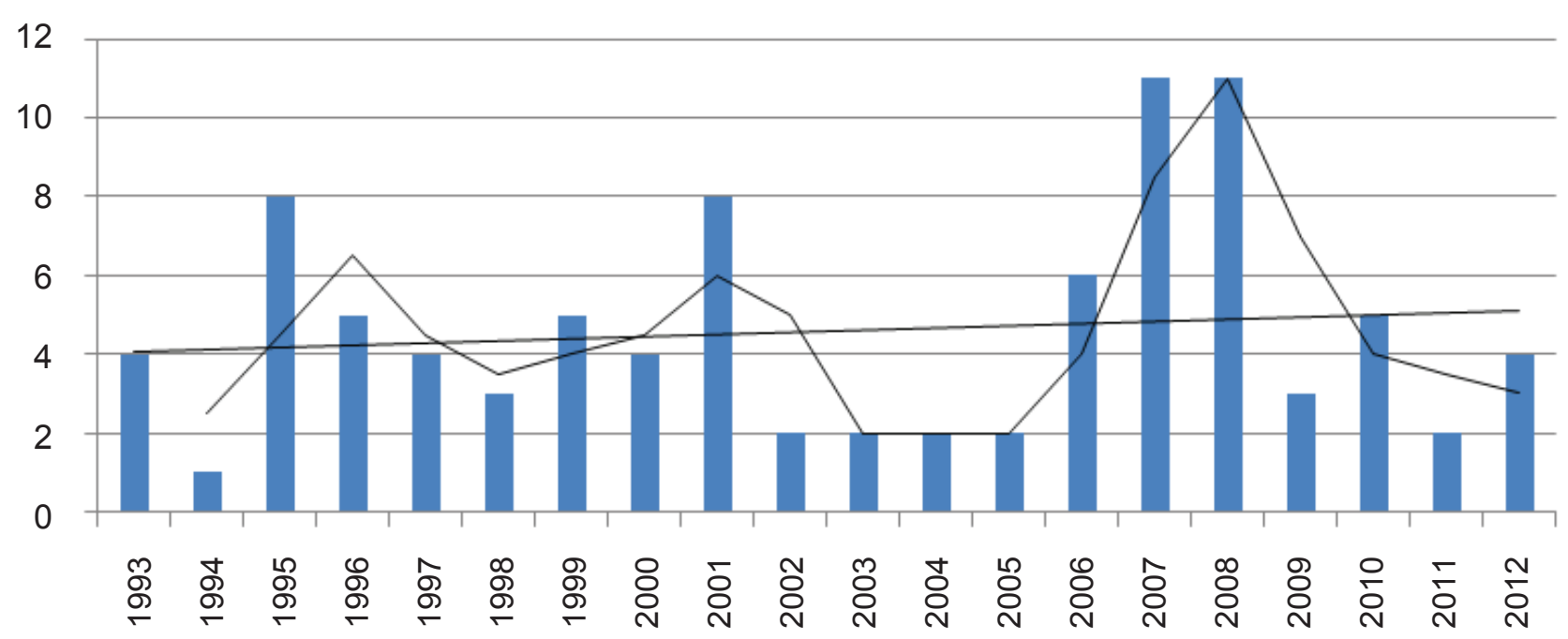

Source: own calculation based on database One Banker - Deals - SDC

As far as the economic sectors are concerned, we can see that these are manufacturing industry $(28 \%)$, consumer staples $(15 \%)$, energy \& power $(14 \%)$ and materials $(11 \%)$.

If we evaluate the data in detail, we can distinguish four periods time:

- 1993-1997: 17 deals and fusions in consumer staples, energy \& power and the manufacturing industry

- 1999-2001: 21 deals and fusions in energy \& power, manufacturing industry, finance and high technology

- 2002-2005: 9 deals and fusions in energy \& power, manufacturing industry and finance

- 2006-2008: 28 deals and fusions in the manufacturing industry, consumer staples and healthcare 


\section{Economic Sectors Analysis of Mergers \& Acquisitions in the Czech Republic}

We should analyze the different economic sectors in detail in order to better understand the key M\&A issues in international business. Do the horizontal or vertical investments prevail among the completed deals? In order to answer this question, we should look carefully about the analysis we have made with the cross-tabulation of economic sectors between acquirer economic sectors and target economic sectors. If we find some differences, we should find a way to explain them or consider them as a diversification of the strategy of the firms. Our main problem is to deal with conglomerate groups, which are extremely diverse and they typically focus on multiple economic sectors.

Table 5 presents the French firms' strategies. More precisely, it displays whether the French firms invested in their core activities or if they used M\&A to diversify their portfolio of activities.

Table 5 | Type of investments (core activities or diversity) of French-Czech Firms

\begin{tabular}{|l|c|c|c|}
\hline & Core activities & Diversity & Total \\
\hline Consumer Products \& Services & 5 & 2 & 7 \\
\hline Consumer Staples & 10 & 1 & 11 \\
\hline Finance & 8 & & 3 \\
\hline Healthcare & 3 & & 4 \\
\hline High Technologies & 4 & 6 & 33 \\
\hline Manufacturing Industry & $\mathbf{2 7}$ & 6 & 12 \\
\hline Materials & 2 & 2 & 4 \\
\hline Media \& Entertainment sector & 1 & & 1 \\
\hline Real Estate & 2 & 1 & 3 \\
\hline Retail Sector & & $\mathbf{1 9}(\mathbf{2 2} \%)$ & $\mathbf{8 7}$ (100\%) \\
\hline Telecommunication sector & $\mathbf{6 8}$ (78\%) & & \\
\hline Total & & & 3 \\
\hline
\end{tabular}

Source: own calculation based on database One Banker - Deals - SDC

We can observe that $78 \%$ of French Enterprises used mergers and acquisitions to invest in their core business. Only $22 \%$ of French enterprises used them to diversify their portfolio of activities.

As for the type of investment, the data in Table 6 suggest that there were 45 acquisitions (49\%) with full French ownership, 30 firms invested in order to have the majority in the Czech firms (33\%) and only 17 French Firms invested by taking over only minorities stakes $(18 \%)$. 
Table 6 | Type of investment (majority, minority, total acquisition)

\begin{tabular}{|c|c|c|c|}
\hline & $\begin{array}{c}\text { Minorities } \\
(50 \%<)\end{array}$ & $\begin{array}{c}\text { Majorities } \\
(>50 \%)\end{array}$ & $100 \%$ Ownership \\
\hline Consumer Products \& Services & 0 & 1 & 4 \\
\hline Consumer Staples & 4 & 4 & 6 \\
\hline Energy and power & 4 & 4 & 5 \\
\hline Financials & 0 & 5 & 3 \\
\hline Healthcare & 2 & 1 & 1 \\
\hline High Technologies & 0 & 2 & 2 \\
\hline Manufacturing Industry & 3 & 10 & 13 \\
\hline Materials & 3 & 2 & 5 \\
\hline Média \& Entertainment & 1 & 1 & 2 \\
\hline Real Estate & 0 & 0 & 1 \\
\hline Retail Sector & 0 & 0 & 2 \\
\hline Telecommunications & 0 & 0 & 1 \\
\hline Total & 17 & 30 & 45 \\
\hline Percentage & $18 \%$ & $33 \%$ & $49 \%$ \\
\hline
\end{tabular}

Source: own calculation based on database One Banker - Deals - SDC

Figure 3 | Trade deficit of France (2010-2015)

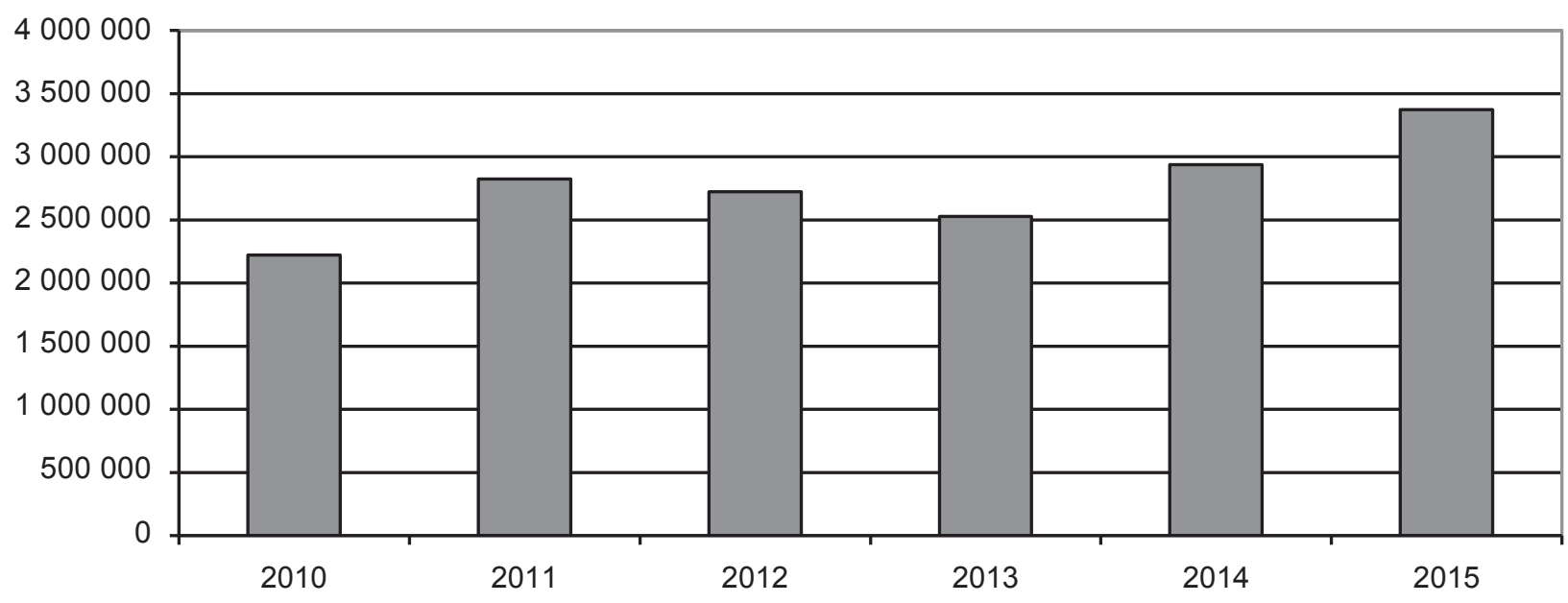

Source: Trademap (2017).

Due to the industrial tradition of the Czech lands, the manufacturing industry represented the most interesting sector for French investors. French companies usually had the majority ownership. Nowadays, many big French players are present in the Czech 
manufacturing sector, for example Alstom, Bouygues, Cegelec, Dalkia, Eiffage, Faurecia, Ondeo-Suez, PSA, Schneider Electric, Valeo, Veolia, Vinci, etc.

If we look at the trade balance of the two countries, we can see a constant deficit of France in trade relations with the Czech Republic. Since 2005, the French import has increased by $180 \%$ and in 2015 , for example, the trade deficit represented 3.37 bil. EUR. When we analyze importation by sectors, the manufacturing industry is clearly dominating, mainly because of the export of the French owned production plants to their home country.

\section{Examples of Good Practices - Consumer Staples and Financial Services}

During the socialist era, state-owned companies dominated the local market and consumers had access to a very limited range of low-quality goods and services (Machek, 2012). In this section, we will illustrate the successful role of French firms in the transformation of the Czech market on the examples of the cheese market and market of financial services.

\subsection{Consumer Staples}

In the consumer staples sector, we find merely ten acquisitions in the core activities of the acquirers. Three major French companies are active in this sector: Fromageries Bel SA with four majority participants, Lactalis SA with three acquisitions and Bongrain SA with three acquisitions, all of them in their core activities. These investors used similar strategies. They made acquisitions of a local company and use the intercultural business approach. In the Czech Republic, they are producing both Czech and international brands. The main goal of such acquisitions is to serve local consumers with an adapted offer.

Bongrain entered the Czech market in 1993 by acquiring the firms Pribina Prribyslav and Povltavské mlékárny Sedlčany, later, 1999, Bongrain bought the company TPK Hodonín (Saadouni, 2016). The three entities merged and today, they use a new brand of the French group Savencia Fromage\&Diary. The company's website states: "In each of the countries where we are present, we offer consumers products designed for them and backed by premium brands which are often part of their national heritage. Our development is built on an intimate knowledge of local tastes and habits, a wealth of cheese-manufacturing know-how, an extensive mastery of cheese-making and dairy technologies and cutting-edge research into milk's constituents" (Savencia, 2017). To illustrate the efficiency of the intercultural business approach, we can mention several successful Czech brands, for instance: Sedlčanský, Král Sýrů, Lučina, Apetito and Pribináček.

Fromageries Bel entered the Czech market in 1995 by using the piggyback strategy. The distribution was done by an intermediary of Danone until 2005. In 2000, the first acquisition of the manufacturing company Želetavské sýrárny occurred and in 2003, Bel acquired the company Sýrárna Klatovy (Agral.cz, 2010). All activities, including production, were concentrated under the Bel Sýry Česko a.s. company brand. In 2010, Bel Sýry sold one factory in Jaroměrice and today, there is only one production site in the Czech Republic. The main Czech brands are Smetannito, Želetava and Tomík. The global brand "Vache qui rit" is using its Czech translation "Veselá kráva" and the taste is adapted to local consumers. 
Lactalis was the last French acquirer in the Czech dairy business. In 2007, two important acquisitions (Mlékárny Kunín, Mlékárna Klatovy) were realized (Denik.cz, 2007) and today, the main Czech brand is Mlékárny Kunín.

In 2014, Savencia's market share was 12\%, Fromageries Bel 7\% and Lactalis 3\% on the Czech cheese market (Lactalis is focusing more on other diary milk products than on the cheese market). The cheese market is fragmented and the main competitors are private labels with $34 \%$ of the total $(\mathrm{GfK}, 2015)$. But the purchasing power is growing as well as the consumption of cheese - it reaches up to about $17 \mathrm{~kg}$ per capita (Týden.cz, 2014). In the medium term, the quality of branded cheeses should become more important for Czech consumers and this is why the Czech market remains promising for the Frenchowned companies.

\subsection{Financial Services}

In the financial sector, we found 10 deals which concern the core activities of financial companies. Two French commercial banks, Société Générale SA and Credit Agricole SA (with his subsidiary from Sofinco of Belgium) acquired the majority stake in Czech companies. All companies are targeting the Czech market and they offer services to both local customers and international clients based in the Central European region.

According to the data retrieved from the Thomson ONE Banker - Deals - SDC PLATINUM database, in 2001, Société Générale acquired 22805911 ordinary shares in Komerční banka (KB), from the Ministry of Finance, for 1754 CZK (52 EUR/\$44. 72) per ordinary share, or a total value of 40.015 bil CZK. Komerční banka was the last Czech non-privatized bank and SG had to struggle with UniCredito and HypoVereinsbank to acquire $60 \%$ of the capital. Today, KB is the third largest bank in Czech Republic, with up to 1.6 million customers (Hovorka, 2015). The bank has a leading position in corporate and investment banking on the Czech market. It provides services to more than $70 \%$ of all medium and large corporations and is the main bank for more than $40 \%$ of these corporations $(\mathrm{KB}, 2015)$. SG is offering a wide range of special financial services such as factoring (Factoring KB), leasing and loans (SGEF, ADL Automotive, ESSOX), insurance (KB Penzijní společnost, KB Pojišt'ovna) in subsidiary companies.

In 2005, Sofinco of Belgium, a unit of Credit Agricole SA, acquired CP Leasing, a Prague-based provider of financing services from Česká Pojišt’ovna, a unit of PPF Group.

Three other deals concerned Czech subsidiaries or Czech societies with strong links with French financial companies, such as AXA SA, or Cetelem SA. For example, AXA SA acquired an undisclosed minority stake, in AXA Penzijní fond AS, a Brno-based provider of insurance and financial services, from the European Bank for Reconstruction. AXA acquired also a minority stake in AXA Životní pojišt'ovna, a Prague-based provider of insurance and financial services, from European Bank for Reconstruction. Cetelem, a unit of BNP Paribas SA's majority-owned Paribas SA subsidiary, acquired the remaining 35\% stake in CETELEM ČR a.s, a provider of consumer credit services, from První městská banka (PMB). From 1995 until May 2015 CETELEM ČR a.s. had been the leading provider of non-banking loans. As of June 2016, the Czech company merged with the mother bank BNP Paribas Personal Finance SA and had acquired the license for banking services. Since this moment, CETELEM has been the trade mark/brand name of the bank used on the Czech market. 


\section{Discussion}

Following our analysis, we can observe that globally, some economic sectors are more important than others in terms of FDI. Most of French-Czech M\&A have been oriented towards manufacturing sectors, energy \& power sectors, consumer staples sectors and financial services. These sectors generate more FDI in other countries as well.

Using the eclectic paradigm (Dunning, 2001), we can understand the relevance of this framework proposed by the triumvirate of OLI variables, in order to understand the portfolio investment strategy of French firms in Czech Republic.

The "L" advantage of the Czech Republic is documented by a favorable development of the main economic indicators as well as the geographical location in the hearth of Europe, which attracts foreign investors. But also, as we could see in the analysis of economic sectors, one of the specifics of French firms which invested in the Czech Republic was the fact that they have already enjoyed $\mathrm{O}$ advantages in their home market, such as in the case of manufacturing or energy \& power sector. This framework also explains why French enterprises invest outside their core business.

\section{Conclusion}

International investments are increasingly organized within so-called global value chains, where the different stages of the production process are located across different countries. The presented analysis helps us understand the historical evolution of mergers and acquisitions of French enterprises in Czech Republic and their main motivations.

French enterprises have massively invested in Czech Republic to acquire new markets and to benefit from the attractiveness of the Czech economy, especially a qualified and relatively cheap labor force, as well as a favorable geographical location. Investments occurred in all economic sectors which, in our view, well illustrates the dynamism of the Czech Republic and its integration in the European Union. However, French investors concentrated on four main economic sectors: the manufacturing industry, energy \& power sector, consumer staples and financial services. In the case of consumer staples, French companies targeted the local market by offering products adapted to Czech consumer's needs and wants. Financial services are also targeted the local market, but services are offered to both Czech customers and international clients doing business in Central Europe. The main aim of M\&A in manufacturing industry is different. Production plants are producing partly to cover the local market's needs, but manufactured products are mostly exported. As for the ownership structure, French had privileged the full ownership or majority stakes in acquired companies.

Future research could be oriented in multiple directions. First, a quantitative analysis of a longer time-series could help us better understand the factors influencing investors' decisions to realize mergers and acquisitions. Also, the characteristics of investors will be country-dependent; a better insight into the behavior of firms from the other most heavily-investing countries in the Czech market would be of theoretical, but also practical importance. 


\section{References}

Agral.cz (2010). Skupina Bel v České republice. Potravinářská revue, 2010(6), 39-41. Retrieved February 10, 2017, from http://www.agral.cz/LinkClick. aspx?fileticket $=$ afeLTdpMoZQ\%3D\&tabid=730\&language $=$ cs - CZ.

Canabal, A., \& White, G. O. (2008). Entry mode research: Past and future. International Business Review, 17(3), 267-284.

Chalençon, L. (2012). Stratégies de localisation et Fusions-Acquisitions: une étude exploratoire. Paper presented at the $2^{\text {nd }}$ annual conference Atlas/AFMI, Lyon, May $31^{\text {st }}-$ June $1^{\text {st }}, 2012$.

Chalençon, L., \& Dominguez, N. (2014). John H. Dunning. Le paradigme éclectique de l'internationalisation. In U. Mayrhofer (Ed.), Les Grands Auteurs en Management International, Colombelles: Editions Management \& Société.

Chalençon, L., \& Mayrhofer, U. (2015). Location of mergers and acquisitions in mature and emerging economies. Paper presented at the 41st Annual EIBA (European International Business Academy) Conference, Rio de Janeiro, December 1-3, 2015.

ČNB (2016). Foreign Direct Investment in 2014. Statistic and Data Support Department, Balance of Payments and Economics Statistics Division. Czech National Bank. Retrieved December 15, 2016 from https://www.cnb.cz/miranda2/export/sites/www.cnb.cz/en/statistics/ bop_stat/bop_publications/pzi_books/PZI_2014_EN.pdf.

Denik.cz (2007). Francouzský Lactalis ovládl Mlékárnu Kunín. Denik.cz [online]. Retireved February 11, 2017 from http://moravskoslezsky.denik.cz/podnikani/zh_mlekarna_ kunin_lactalis_200.htmlhttp://moravskoslezsky.denik.cz/podnikani/zh_mlekarna_kunin_ lactalis_200.html

DePamphilis, D. (2008). Mergers, acquisitions, and other restructuring activities: An integrated approach to process, tools, cases, and solutions. Academic Press.

Dunning, J. H. (2000). The eclectic paradigm as an envelope for economic and business theories of MNE activity. International Business Review, 9(2), 163-190.

Dunning, J. H. (2001). The eclectic (OLI) paradigm of international production: past, present and future. International Journal of the Economics of Business, 8(2), 173-190.

Fan, J. P., \& Goyal, V. K. (2006). On the patterns and wealth effects of vertical mergers. The Journal of Business, 79(2), 877-902.

Florida, R. (1995). Towards the learning region. Futures, 27(5), 527-536

GfK (2015). INCOMA GFK Shopping Monitor.

Hovorka, J. (2015). Jak velké jsou banky v Česku? Nový žebříček klientů i vkladů.

Aktuálně.cz [online]. Retrieved February 12, 2017 from https://zpravy.aktualne.

cz/finance/jak-velke-jsou-banky-v-cesku-novy-zebricek-klientu-i-vkladu/

$r \sim c 6 b 9 b 70$ efe0211e499590025900fea04/?redirected=1487598168.

Johanson, J., \& VahIne, J.-E. (1977). The Internationalization Process of the Firm: A Model of Knowledge Development and Increasing Foreign Market Commitments. Journal of International Business Studies, 8(1), 23-32.

Johanson, J., \& VahIne, J.-E. (2009). The Uppsala Internationalization Process Model Revisited: From Liability of Foreignness to Liability of Outsidership. Journal of International Business Studies, 40(9), 1411-1431.

KB (2015). Komerční banka. Annual report 2015. Retrieved February 20, 2017 from https:// www.kb.cz/file/en/about-bank/investor-relations/publications/annual-reports/kb-2015annual-report.pdf?2079ac9a8c9b93989d387f79c46dd7f.

Machek, M. (2012). Retail Market Structure Development in Central Europe. Central European Business Review, 1(3), 22-27. 
Machková, H., Král, P. \& Lhotáková, M. (2010). International Marketing, Theory, Practices and New Trends. Prague: Oeconomica.

Machková, H., \& Collin, P.-M. (2015). Market Entry Strategies of Passenger Carmakers The Case Study of the Czech Republic. Central European Business Review, 4 (3), 23-34.

Mayrhofer, U. (2012). Management of Multinational Companies: A French Perspective. Basingstoke: Palgrave Macmillan.

Mayrhofer, U., \& Urban, S. (2011). Management international: Des pratiques en mutation. Paris: Pearson education.

Mohelský, L., \& Machková, H. (2012). Is diversification as a Strategic Advantage? The Example of Automotive Components in the Czech Republic. Central European Business Review, 1(2), 37-45.

Rugman, A. M., \& Verbeke, A. (2004). A perspective on regional and global strategies of multinational enterprises. Journal of International Business Studies, 35(1), 3-18.

Rugman, A. M. (2010). Reconciling internalization theory and the eclectic paradigm, Multinational Business Review, 18(2), 1-12.

Saadouni, S. (2016). Tradiční výrobce oblíbené Lučiny a Pribináčku změnil název firmy. Denik. cz [online]. Retrieved January 2, 2017 from http://www.denik.cz/ekonomika/tradicnivyrobce-oblibene-luciny-a-pribinacku-zmenil-nazev-firmy-20160110-oj2f.html

Savencia (2017). Profile. Savencia-Fromage \& Diary [online]. Retrieved February 2, 2017 from http://www.savencia-fromagedairy.com/en/profile/.

Tort, E. (2010). L'essentiel des fusions et Acquisitions. Paris: Ed. Gualino.

Trademap (2017). Trademap: Trade statistics for international business development. Retrieved January 25, 2016 from www.trademap.org/Bilateral_TS.aspx.

Týden.cz (2014). Češi jedí stále více sýrů, přibývá sýroték. Retrieved February 2, 2017 from http://www.tyden.cz/rubriky/relax/apetit/cesi-jedi-stale-vice-syru-pribyvasyrotek_298627.html.

UNCTADSTAT (2014a). Country Profiles. Czech Republic. Retrieved January 10, 2017 from http://unctadstat.unctad.org/CountryProfile/GeneralProfile/en-GB/203/index.html.

UNCTADSTAT (2014b). Frequently Asked Questions. Retrieved January 10, 2017 from http://unctadstat.unctad.org/EN/FAQ.html.

Valdemarin, S. (2015). Analysis regarding the growing presence of Italian firms in Romania. Central European Business Review, 4(4), 58-69

\section{Authors}

\section{Dr. Eric Thivant}

University of Lyon, Jean-Moulin - iaelyon

Magellan Research Centre

6 cours Albert Thomas 69355 Lyon Cedex 08

France

eric.thivant@univ-lyon3.fr

\section{Prof. Ing. Hana Machková, CSc.}

Rector

University of Economics, Prague

Nam. W. Churchilla 4, 13067 Prague 3

Czech Republic

machkova@vse.cz 